\title{
A NOVAÇÃO NA RECUPERAÇÃO JUDICIAL
}

\section{THE NOVATION IN JUDICIAL RECOVERY}

\author{
${ }^{1}$ Ana Carolina Cunha Brandão \\ ${ }^{2}$ Tereza Cristina Monteiro Mafra
}

\section{RESUMO}

Através de uma análise da novação disciplinada pela Lei Civil, e uma análise sobre a novação recuperacional, o presente trabalho almeja demonstrar, de maneira lógica e coerente, se a novação prevista na Lei $\mathrm{n}^{\circ} 11.101 / 2005$ é uma espécie diferente da novação tradicional, considerando a prevista na Lei Civil, uma exceção ou se tratasse do mesmo instituto. Para a condução deste trabalho foi utilizado o método exploratório, de modo que o objeto foi estudado por meio de coleta e estudo de doutrina, artigos científicos, jurisprudência e Leis que retratam o tema em questão.

Palavras-chave: Novação, Recuperação judicial, Garantias

\begin{abstract}
Through an analysis of novation disciplined by civil law, and an analysis of the novation in judicial recovery, this paper intends to demonstrate, in a logical and coherent way, if the novation previse in Law $\mathrm{n}^{\circ}$. 11,101 / 2005 is a different kind of traditional novation, considering the one is previse in the Civil Law, an exception or if it was the same institute. To conduct this study was used the exploratory method, and the object has been studied by collecting and doctrine study, scientific articles, case law and laws that portray the subject in question.
\end{abstract}

Keywords: Novation, Judicial recovery, Guarantees

\footnotetext{
${ }^{1}$ Mestranda em Direito pela Faculdades Milton Campos -FMC, Minas Gerais, MG. (Brasil). Advogada associada no escritório Rabelo, Ribeiro e Romanelli - Advogadoa. E-mail: anacarolbrandao@ yahoo.com.br.

${ }^{2}$ Doutora em Direito da Universidade Federal de Minas Gerais - UFMG, Minas Gerais, MG. (Brasil). Professora na Faculdades Milton Campos, FMC, Minas Gerais, MG. /(Brasil). E-mail: tereza.c.mafra@terra.com.br.
} 


\section{INTRODUÇÃO}

A palavra novação origina-se da expressão latina novatio, sendo uma ação de renovar, uma renovação. A novação pode ser conceituada como sendo a extinção de uma obrigação pela formação de outra, destinada a substituí-la.

A novação surgiu no direito romano, e após sofre adaptações necessárias frente ao direito moderno, foi disciplinada no Código Civil, pelos arts. 360 a 367.

O presente trabalho tem como objetivo demonstrar se a novação disposta no art. 59 da Lei $n^{\circ} 11.101 / 2005$ pode ser considerada como a novação tradicional, como a disciplinada na Lei Civil (Lei n¹0.406/2002), ou seria uma nova espécie de novação.

Será feita uma análise da novação tradicional da Lei Civil discorrendo-se sobre seus requisitos, objetivos e efeitos; e após será feita uma análise sobre a novação recuperacional, discorrendo-se sobre seus requisitos, objetivos e efeitos sob a ótica da Lei $n^{\circ}$ 11.101/2005.

O presente trabalho almeja, assim, demonstrar, de maneira lógica e coerente, se a novação prevista na Lei n 11.101/2005 é uma espécie diferente da novação tradicional, prevista na Lei Civil, uma exceção ou se tratasse do mesmo instituto.

Para a condução deste trabalho foi utilizado o método exploratório, de modo que o objeto foi estudado por meio de coleta e estudo de doutrina, artigos científicos, jurisprudência e Leis que retratam o tema em questão.

Dessa forma, dividiu-se a pesquisa em quatro partes. Partiu-se da análise da novação disciplinada pela lei civil (Lei $n^{\circ} 10.406 / 2002$ ), seguida pela novação prevista na Lei $n^{\circ}$ 11.101/2005. Foi feita uma análise dos requisitos e efeitos da novação na Lei Civil e na Lei de Falência e Recuperação. Após, passou-se a análise da jurisprudência do Superior Tribunal de Justiça sobre a novação recuperacional.

Ao final, verifica-se que apesar de não haver uma unanimidade na doutrina, e na jurisprudência, a novação recuperacional não pode ser considerada um instituto idêntico ao da novação da Lei Civil, por ter uma condição resolutiva, diretamente ligada ao sucesso ou não do plano de recuperação judicial.

Espera-se que ao final sejam atingidos os objetivos propostos. 
Com a evolução da sociedade, e das relações obrigacionais, essa imutabilidade passou a ser um empecilho, uma vez que a transmissão de créditos e débitos se tornou imprescindível. A fim de resolver tal impasse, surgiu o instituto da novação, como um modo de transferir a obrigação, extinguindo-se a obrigação anterior pela criação de uma nova. (DINIZ, 2007, p. 287)

Apesar de ser uma nova obrigação, a prestação objeto da obrigação anterior, e a objeto da nova ordem, deviam ser idênticas. A novação, só era válida, quando o objeto da dívida continuava o mesmo; havia, portanto, uma transfusão ou translação da dívida anterior, ou seja, o débito continuava o mesmo, mas era transferido, através de uma nova obrigação, a um novo credor ou devedor. (DINIZ, 2007, p. 288)

No direito moderno, por não mais existir a impossibilidade de transmissão das relações obrigacionais, já que são elas eminentemente transmissíveis, o instituto da novação, como foi concebido no direito romano, e era utilizado desde então, perdeu sua importância.

O Código Civil de 2002 trouxe algumas mudanças estruturais e funcionais no conceito de novação, a fim de atender as relações obrigacionais existentes, sendo tais mudanças muito bem pontuadas pela autora Maria Helena Diniz:

a moderna novação não obedece a nenhuma forma especial; opera-se pela extinção de uma obrigação existente, mediante a constituição de uma nova, que a substitui, havendo, portanto, uma substituição e não uma translação do conceito material de uma na outra, pressupondo a diversidade substancial da obrigação. No direito romano, a novatio se processava por meio da stipulatio, forma especial de que se revestia, e permitia uma íntima relação entre as duas obrigações, determinada pelo transporte de matéria patrimonial, econômica, de uma na outra, devendo haver identidade de conteúdo entre ambas. Entre a novação antiga e a moderna subsistiu o requisito do animus novandi. (DINIZ, 2007, p. 290)

A novação está disciplinada nos artigos 360 a 367 do Código Civil ${ }^{1}$ e, pode ser conceituada como uma forma de pagamento indireto na qual ocorre a substituição de uma obrigação anterior por uma nova obrigação, diversa da primeira. O principal efeito é a extinção da dívida primitiva, junto com todos os acessórios e garantias a ela relacionados, desde que não haja estipulação em contrário. (TARTUCE, 2015, p. 176)

\footnotetext{
${ }^{1}$ Código Civil - Art. 360. Dá-se a novação:

I - quando o devedor contrai com o credor nova dívida para extinguir e substituir a anterior;

II - quando novo devedor sucede ao antigo, ficando este quite com o credor;

III - quando, em virtude de obrigação nova, outro credor é substituído ao antigo, ficando o devedor quite com este.
} 
Não visa, a novação, à extinção de uma obrigação preexistente para criar uma nova, ela apenas cria uma nova relação obrigacional para extinguir a anterior, com a intenção de criar para extinguir. Um novo vínculo obrigacional é criado para extinguir o anterior, de modo que não há uma satisfação imediata do crédito, uma vez que o credor não recebe a prestação devida, mas apenas adquire um outro direito de crédito ou passa a exercer um direito contra outra pessoa. (DINIZ, 2007, p. 291)

O instituto da novação é simultaneamente causa extintiva e geradora de obrigações: um extintivo, que diz respeito a antiga obrigação, e outro gerador, relativo a nova. A nova obrigação substitui a anterior.

Toda novação tem natureza jurídica negocial, portanto nunca poderá ser imposta por lei, uma vez que sempre depende de uma convenção firmada entre os sujeitos da relação obrigacional. A respeito da natureza jurídica da novação, assim preleciona Orlando Gomes:

A extinção da divida por novação opera-se em consequência de ato de vontade dos interessados; jamais por força de lei. Diz-se, por isso, que a novação tem natureza contratual. Resulta, efetivamente, do concurso de vontades. Exige-se, por essa razão, que as partes observem os requisitos necessários à validade dos contratos em geral. Seria, em suma, contrato liberatório. (GOMES, 2008, p.166)

\subsection{DOS REQUISITOS DA NOVAÇÃO}

Para ser caracterizada a novação é necessário a presença de certos requisitos, quais sejam: a existência jurídica de uma obrigação; a constituição de uma nova obrigação; e o animus novandi.

Art. 361. Não havendo ânimo de novar, expresso ou tácito mas inequívoco, a segunda obrigação confirma simplesmente a primeira.

Art. 362. A novação por substituição do devedor pode ser efetuada independentemente de consentimento deste.

Art. 363. Se o novo devedor for insolvente, não tem o credor, que o aceitou, ação regressiva contra o primeiro, salvo se este obteve por má-fé a substituição.

Art. 364. A novação extingue os acessórios e garantias da dívida, sempre que não houver estipulação em contrário. Não aproveitará, contudo, ao credor ressalvar o penhor, a hipoteca ou a anticrese, se os bens dados em garantia pertencerem a terceiro que não foi parte na novação.

Art. 365. Operada a novação entre o credor e um dos devedores solidários, somente sobre os bens do que contrair a nova obrigação subsistem as preferências e garantias do crédito novado. Os outros devedores solidários ficam por esse fato exonerados.

Art. 366. Importa exoneração do fiador a novação feita sem seu consenso com o devedor principal.

Art. 367. Salvo as obrigações simplesmente anuláveis, não podem ser objeto de novação obrigações nulas ou extintas. 
Considerando o fato de ser a novação a constituição de uma nova obrigação, que visa extinguir e substituir a anterior, é imprescindível que a obrigação a ser novada seja válida, não podendo ser objeto de novação uma obrigação nula. Caso seja a obrigação anterior anulável, ela também pode ser novada, uma vez que tem existência válida até ser anulada. (GOMES, 2008, p. 167)

Nos casos de uma obrigação anulável, para a validade da novação, é necessário observar se há o conhecimento ou não das partes, a respeito do defeito que poderá ensejar a anulação. Em sendo uma novação ativa, e o devedor ignorava a possibilidade de anulação da obrigação anterior, a nova poderá ser anulada. Em contrapartida, sendo a novação passiva, e o devedor não tinha conhecimento, a obrigação, ainda que novada, continua podendo ser apenas anulável. (GOMES, 2008, p. 167)

A obrigação extinta não pode ser novada, uma vez que não é possível novar uma obrigação que não existe, porém, uma dívida prescrita pode ser novada. O fato de estar a obrigação prescrita não significa que ela não pode mais ser cumprida, e a partir do momento em que a prescrição pode ser renunciada, após sua consumação, o devedor que aceita a novação de uma dívida prescrita está tacitamente renunciando o direito de invocar a prescrição. (GOMES, 2008, p. 167)

A nova obrigação deve ser substancialmente diversa da primeira, destinada a substituir e extinguir a anterior, ou seja, o conteúdo da obrigação precisa ter sofrido uma modificação substancial, ainda que o objeto da prestação não tenha sido alterado. Apenas a concessão de um prazo mais favorável ou uma simples alteração de garantia não é suficiente para que haja a novação. (STOLZE, 2011, p. 219/220)

Nesse sentido, observa Orlando Gomes:

Conforme a doutrina moderna, a novação só se configura, ao contrário do que ocorria no Direito romano, se houver diversidade substancial entre as suas dívidas, a nova e a anterior. Não há novação, quando apenas se verifiquem acréscimos ou outras alterações secundárias na dívida, como, por exemplo, a estipulação de juros, a exclusão de uma garantia, o encurtamento do prazo de vencimento, e, ainda, a oposição de um termo. (GOMES, 2008, p. 166)

A intenção de novar (animus novandi), é o elemento psíquico da novação, uma vez que para acontecer a novação é necessário que as partes interessadas queiram a criação da nova obrigação, com a extinção da anterior. A presença desse requisito é tão importante que o Código Civil o trouxe expresso em seu art. 361, ao dizer que: "Não havendo ânimo de novar, expresso 
ou tácito mas inequívoco, a segunda obrigação confirma simplesmente a primeira." O animus de novar não deve ser presumido, mas sim expresso, tacitamente ou expressamente, seja pelas partes, ou como resultado inequívoco da natureza das obrigações. (DINIZ, 2007, p. 295)

A respeito do animus novandi, assim se posiciona Caio Mário da Silva Pereira:

Pode vir o animus novandi expressamente deduzido no instrumento, e então tollitur quaestio. Na ausência, porém, de menção específica, deve ser apurado se o conjunto de circunstâncias autoriza afirmar se se configura implicitamente, porém de maneira inequívoca. Quer isto dizer que nunca se presume a novação, pois o contrário dissonaria da sua natureza extintiva do vínculo, devendo resultar sempre da vontade das partes. O que se faculta é, tão-somente, na apuração desta vontade, aceitar-se, a par da declaração explícita, a claramente dedutível dos termos da nova. (PEREIRA, 2005, $p$. 248)

Na prática não é fácil atestar a configuração do animus novandi. Uma das formas utilizadas para tal confirmação é o critério da incompatibilidade. Quando a segunda obrigação é incompatível com a primeira, constata-se o ânimo de novar. (PEREIRA, 2005, p. 248)

\subsection{DAS ESPÉCIES DE NOVAÇÃO}

Existem três espécies de novação: a objetiva, a subjetiva, e a mista. ${ }^{2}$

A novação objetiva é a modalidade mais comum e ocorre nas hipóteses nas quais o devedor contrai com o credor uma nova dívida a fim de extinguir a primeira (art. 360, I, do CC). As partes envolvidas na obrigação continuam as mesmas, mas é criada uma nova obrigação para substituir e extinguir a anterior. (TARTUCE, 2015, p. 180/181)

Na novação subjetiva há a substituição de uma das partes envolvidas na obrigação, razão pela qual essa modalidade de novação se subdivide em três hipóteses: (i) por mudança do devedor (novação subjetiva passiva); (ii) por mudança do credor (novação subjetiva ativa); e

(iii) por mudança de credor e devedor (novação subjetiva mista).

Há novação subjetiva passiva quando um novo devedor sucede ao antigo, ficando o credor quite em relação a este. Não é necessário que haja uma modificação no objeto da obrigação, mas apenas dos sujeitos. A doutrina entende que a novação subjetiva passiva pode

\footnotetext{
${ }^{2}$ Código Civil, Art. 360. Dá-se a novação:

I - quando o devedor contrai com o credor nova dívida para extinguir e substituir a anterior;

II - quando o novo devedor sucede o antigo, ficando este quite com o credor;

III - quando, em virtude de obrigação nova, outro credor é substituído ao antigo, ficando o devedor quite com este.
} 
existir de dois modos: por expromissão e por delegação. (STOLZE, 2011, p. 224)

A novação subjetiva passiva por expromissão acontece quando a substituição do devedor se dá por simples ato do credor, independentemente do consentimento do devedor substituído. Já a novação subjetiva passiva por delegação acontece quando o devedor indica uma terceira pessoa que assumirá o débito, com a anuência do credor. (STOLZE, 2011, p. 224)

Já a novação subjetiva ativa se dá quando há uma alteração do credor da relação jurídica obrigacional (art. 360, II, do CC).

Por fim, a novação mista ocorre quando além da alteração do sujeito (credor ou devedor), há, também, uma mudança no conteúdo ou objeto da relação obrigacional.

\subsection{DOS EFEITOS DA NOVAÇÃO}

Com relação a obrigação extinta através da novação, tem-se os seguintes efeitos: (i) a paralisação dos juros relativos ao débito extinto; (ii) a extinção de todas as garantias e acessórios, salvo quando há estipulação em contrário (art. 364, CC); (iii) o desaparecimento do estado de mora do devedor; (iv) a subsistência de preferências e garantias do crédito novado, nas hipóteses disciplinadas no art. 365, CC; (v) a perda, por parte do devedor, do benefício de todas as exceções resultantes da antiga obrigação; (vi) a extinção das ações ligadas à obrigação anterior; (vii) o desaparecimento da fiança que garantia a obrigação extinta (art. 366, CC); e (viii) a insolvência do novo devedor é de responsabilidade única do credor, não podendo o devedor da obrigação anterior ser responsabilizado (art. 363, CC). (DINIZ, 2007, p. 306)

Ao ser realizada a novação são extintos todos os acessórios e garantias existentes na obrigação anterior, salvo quando há estipulação em contrário. Dessa maneira, é possível concluir, que o principal efeito da novação é liberatório. Com isso, temos que se o fiador não consentir com uma novação da obrigação que afiança, ele não poderá ter nenhum tipo de responsabilidade na obrigação novada. Da mesma forma acontece nos casos de garantias reais, que tenha por objeto bem de terceiro, garantidor da obrigação. Apenas se houver a anuência expressa do terceiro garantidor é que as garantias reais persistem na obrigação novada. (STOLZE, 2011, p. 227) 


\section{O INSTITUTO DA NOVAÇÃO NA LEI DE RECUPERAÇÃO E FALÊNCIA}

A fim de contextualizar o instituto da novação presente na Lei ${ }^{\circ} 11.101 / 2005$, Lei de Recuperação e Falência, necessário se faz uma breve análise sobre os objetivos da referida lei.

A insolvência empresarial era regulada pelo Decreto-Lei $n^{\circ} 7.661 / 45$, concebido com base em um modelo de empresa próprio da economia capitalista da época, pós segunda guerra mundial. O objetivo do referido decreto era proteger a pessoa do empresário, e não a atividade econômica organizada. O crédito era concebido como mais uma espécie de relação obrigacional, sendo desconsiderada a repercussão da insolvência no mercado, já que se concentrava no ajustamento das relações entre os credores e o ativo do devedor. (FAZZIO JUNIOR, 2010, p.1)

O Decreto-Lei ${ }^{\circ} 7.661 / 45$ não propiciava a negociação entre o credor e o devedor, sendo um sistema inflexível que acabava por gerar processos demorados e infrutíferos. A Lei de Falência e Recuperação de Empresas, n ${ }^{\circ} 1.101 / 2005$ busca o interesse das partes envolvidas, visando sempre a subsistência da atividade empresária, através da recuperação extrajudicial ou, para o caso de falência, que a empresa seja liquidada da forma mais eficiente possível.

O sistema de recuperação de empresas, disciplinado pela Lei ${ }^{\circ} 11.101 / 2005$, segue a tendência do direito francês e do direito norte-americano, sendo amplas as possibilidades de recuperação da empresa, mediante a participação direta e a fiscalização dos credores, em observância às atuais necessidades econômicas, tendo como principal foco a continuação da atividade exercida pela empresa em crise.

Os objetivos da recuperação judicial estão bem descritos no art. 47 da Lei $\mathrm{n}^{\circ}$ 11.101/2005:

Art. 47. A recuperação judicial tem por objeto viabilizar a superação da situação de crise econômico-financeira do devedor, a fim de permitir a manutenção da fonte produtora, do emprego dos trabalhadores e dos interesses dos credores, promovendo, assim, a preservação da empresa, sua função social e o estímulo à atividade econômica.

Em seus comentários a respeito desse art. 47, supra colacionado, assim se manifesta Jorge Lobo:

Para alcançar esse múltiplo escopo e para atender aos interesses das partes envolvidas e harmonizar os direitos de cada um equanimemente, ao invés do confronto entre devedor e seus credores, impõe-se a cooperação; a luta para a realização dos fins comuns; ao invés da defesa egoística e 


\begin{abstract}
intransigente dos interesses individuais, a busca de soluções solidárias e equitativas, que causem o menor sacrifício a todos, dentro da perspectiva de que se deve priorizar a composição dos interesses conflitantes, raramente convergentes se não houver, de parte a parte, a compreensão $e$ a sensibilidade do que é absolutamente indispensável: salvar a empresa em crise, que demonstre ser econômica e financeiramente viável, com a finalidade precípua de mantê-la empregadora de mão-de-obra, produtora e distribuidora de bens e serviços, criadora de riquezas e de prosperidade, geradora de impostos e, por igual, ao mesmo tempo, respeitar os direitos e interesses dos credores. (LOBO, 2005, p. 109)
\end{abstract}

A recuperação judicial será viável quando a empresa demonstrar, apesar do momento de crise, a viabilidade da continuidade de sua atividade econômica, bem como a possibilidade de uma reorganização eficiente, uma vez que uma das incumbências do regime adotado é proteger de forma harmônica, os interesses dos credores, dos devedores e da própria empresa, como fonte de produção. (FAZZIO JUNIOR, 2001, p. 93)

A Lei $n^{\circ} 11.101 / 2005$ não traz um rol taxativo de meios de recuperação para uma empresa, apresenta, apenas, uma normação essencial, com possibilidades de restruturação que podem ser extrapoladas pelo devedor, ao apresentar seu plano de recuperação, autorizando, até mesmo, soluções consideradas inortodoxas. A lei define uma norma mínima, a fim de impedir que determinada categoria de créditos monopolize os recursos do devedor, em detrimento de outros. Dessa maneira, observado esse mínimo legal, quaisquer espécies de acordos entre os credores de diversas classes e o devedor, são possíveis. (FAZZIO JUNIOR, 2001, p. 114)

O plano de recuperação judicial elaborado pela empresa recuperanda e aprovado pelos credores, em assembleia geral de credores, é homologado pelo poder judiciário, e após a homologação, opera-se a novação dos créditos a ele submetidos, nos termos do que preceitua o art. 59 da Lei n 11.101/2005: "O plano de recuperação judicial implica novação dos créditos anteriores ao pedido, e obriga o devedor e todos os credores a ele sujeitos, sem prejuízos das garantias, observado o disposto no $\S 1^{\circ}$ do art. 50 desta lei”.

A novação dos créditos, do plano de recuperação judicial de uma empresa, é essencial para o sucesso do plano, uma vez que, apenas assim, opera-se a extinção do crédito originário, e obriga os credores, e também a empresa devedora, a cumprir o que foi estabelecido no plano de recuperação judicial. 


\subsection{CARACTERÍSTICAS DA NOVAÇÃO NA RECUPERAÇÃO JUDICIAL}

Jorge Lobo define a recuperação judicial como sendo "[...] um ato complexo, uma vez que pode ser considerada sob vários aspectos, pois abrange um ato coletivo, um favor e uma obrigação ex lege." (LOBO, 2010, p. 172)

A recuperação judicial, seria, portanto, um ato coletivo processual, uma vez que as vontades convergem até formarem uma única vontade, sob a direção e fiscalização do Poder Judiciário; assim como seria, também, um favor legal, a partir do momento em que, mediante o atendimento de alguns requisitos, garante ao devedor a solução da sua crise financeira, através da concessão de benefícios legais. Seria, ainda, uma obrigação ex lege porque após homologado o plano de recuperação, ocorre a novação dos créditos que foram submetidos ao regime de recuperação judicial. (LOBO, 2010, p. 172)

Em que pese o fato de ser necessária a homologação judicial do plano de recuperação, não há dúvidas de que este possui natureza jurídica contratual. Nesse sentido, é a conclusão de Vera Helena de Mello Franco e Rachel Sztajn

Poder-se-á dizer que o plano é um negócio de cooperação celebrado entre devedores e credores, homologado pelo Juiz. No que diz respeito ao negócio de cooperação, assemelha-se ao contrato plurilateral; no que diz respeito à homologação, pode-se considerar forma de garantia do cumprimento das obrigações assumidas, com o que se reduzem custos de transação dada a coercitividade que dela, homologação, resulta. (FRANCO; SZTAJN, 2008, p. 233)

Dessa maneira, a novação prevista no art. 59 da Lei n 11.101/2005 terá, assim como no direito civil, natureza contratual, uma vez que decorre da vontade das partes. Entretanto, ao contrário do que ocorre no direito civil, no âmbito do regime concursal, a novação ocorrerá se for aprovado o plano de recuperação, em assembleia geral de credores, homologado pelo Poder Judiciário, e não pela vontade individual de cada um dos credores.

A novação recuperacional deve atender aos mesmos requisitos necessários para a caracterização de uma novação na lei civil, quais sejam: (i) ser necessária a existência de uma obrigação originaria válida; (ii) a criação de uma nova, com a extinção da anterior; e (iii) o animus novandi.

O animus novandi, na novação recuperacional, não ocorre individualmente, entre a empresa devedora e o credor, em cada uma das obrigações existentes, quando da elaboração do plano de recuperação, mas sim, pela aprovação do plano de recuperação, a qual se dá em 
assembleia de credores, sendo necessário apenas os quóruns determinados pela lei, para sua aprovação, e não a unanimidade.

A partir do momento em que não é necessário a unanimidade de aprovação dos credores, para a aprovação do plano de recuperação em assembleia geral, nem todos os credores podem concordar com o plano apresentado, em alguns casos porque a novação promovida pode ser prejudicial a tais credores, em especial aqueles que tinham suas obrigações garantidas, como por exemplo através de aval, endosso e fiança.

A fim de resguardar esses direitos, o legislador, na contramão do que dispõe a lei civil, determinou que as garantias, das dívidas novadas, não seriam prejudicadas (art. 59, caput, da Lei $\left.n^{\circ} 11.101 / 2005\right)$.

Nesse sentido, assim se manifesta, Jorge Lobo:

Os credores do devedor, embora sujeitos aos efeitos da decisão proferida na ação de recuperação judicial (art. 59), manterão intocados os direitos e privilégios que possuam contra: a) os coobrigados ou co-devedores solidários (p. ex., avalistas e endossantes de títulos de créditos emitidos pelo devedor); b) os fiadores; e c) os obrigados de regresso (art. 49, $\$ 1^{\circ}$ ), podendo deles cobrar, no juízo competente, o que lhes for devido e abater dos créditos habilitados e julgados o que houverem recebido dos coobrigados.

\subsection{OS EFEITOS DA NOVAÇÃO RECUPERACIONAL}

Em que pese o fato de ter a novação recuperacional os mesmos requisitos de constituição da novação civil, elas não são idênticas, e tal diferença fica evidenciada quando observados os efeitos de cada uma.

A Lei n ${ }^{\circ} 11.101 / 2005$ "flexibiliza" a novação, ao dispor no parágrafo $2^{\circ}$ do art. 61 que: "Decretada a falência, os credores terão reconstituídos seus direitos e garantias nas condições originalmente contratadas, deduzidos os valores eventualmente pagos e ressalvados os atos validamente praticados no âmbito da recuperação judicial."

A novação recuperacional é, portanto, condicional, uma vez que, para que surta efeitos é necessário que a condição imposta (sucesso do plano de recuperação judicial) se realize. Em não sendo o plano de recuperação cumprido no prazo de dois anos, após sua homologação, ou sendo decretada a falência da empresa, as garantias e direitos nas dívidas originalmente contratadas voltam a ter validade, e podem ser executadas pelos credores.

A novação condicionada não é um instituto novo, trazido pela Lei ${ }^{\circ} 11.101 / 2005$, tanto que Pontes de Miranda já lecionava sobre o mesmo, elucidando a questão da seguinte maneira: 
5.NOVAÇÃO RESOLUTIVA CONDICIONADA. - A novação pode ser sob condição resolutiva? Preliminarmente, observe-se que se não pergunta se pode ser novada a prior obligatio sob condição resolutiva; a resolutividade, de que se cogita, é o defeito jurídico novatio (cf. VILLAUMEZ, De Navatione obligationum, 18 s.; R. Römer, Die bedingte Novation, 333 s.) A prior obligatio extingue-se, mas outra se estabelece por efeito da novação resolutiva condicionada. A L. 44, § 2, D. de obligationibus ET actionibus, 44, 7, foi invocada em contrário a isso, porque seria inserção posterior de condição; mas não é isso o que se enuncia. Não se trata de ressurgimento da divida extinta, mas de nova obligatio em dois tempos, a obligatio que existe até à resolução e a obligatio que se implante com essa, irradiada do negócio jurídico novativo. Não há identidade entre a prior obligatio e essa nova obligatio, ainda após a resolução.

Não é possível construir-se diferentemente.

A construção de C. DEMOLOMBE (Cours de Code Napoléon, 28, 180), AUBRY e RAU (Cours de Droit civil français, IV, 350) e outros era diferente; resolúvel seria a extinção da prior obligatio. Daí haver a prior obligatio, a nova obligatio e, depois, em virtude da resolução da novação (resolução da extinção da prior obligatio!), mas uma vez a prior obligatio. Isso permitiria renascimento, ressurreição de vinculo, o que repugna aos princípios. (MIRANDA, 1984, p. 112/113)

Segundo Pontes de Miranda, na novação condicional, a obrigação primitiva é completamente extinta, e o que se condiciona a uma resolutividade são os efeitos da nova obrigação assumida, sendo esse o motivo pelo qual ele a classifica como uma novação “ a dois tempos".

A retomada às condições originárias não corresponde a uma ressurreição da obrigação originária (prior obligatio), já novada, mas advém uma segunda obrigação, com as características da obrigação originária. A explicação também é dada por Pontes de Miranda:

Não se trata de ressurgimento da dívida extinta, mas de nova "obligatio" em dois tempos, a "obligatio" que existe até à resolução e a "obligatio" que se implanta com essa, irradiada do negócio jurídico novativo. Não há identidade entre a "prior obligatio" e essa nova "obligatio", ainda após a resolução. (MIRANDA, 1984)

Embora a resolução da condição retome o status quo dos credores com relação aos seus créditos, os atos validamente praticados em observância ao plano recuperacional serão preservados, decotando-se das obrigações originárias os valores pagos aos credores durante o processo de reorganização.

Em alguns casos, ainda que resolvida a novação, alguns créditos, devido aos meios recuperacionais aplicados ao caso específico, não retornarão ao seu status quo anterior ao plano de recuperação, uma vez que, com este, a novação terá sido definitiva. Um exemplo desse tipo 
de impossibilidade acontece nos casos em que foram constituídas sociedades de credores, pois, independentemente da adimplência do devedor com suas obrigações, no prazo de dois anos, ou a falência, a sociedade foi validamente constituída, com a determinação de respectiva participação societária dos credores, não podendo, estes, voltarem ao seu estado anterior. (MUNHOZ, 2005, p. 291)

Ao contrário do que dispõe o Código Civil em seu art. 364, o qual estabelece, de maneira taxativa, que a "novação extingue os acessórios e garantias da dívida, sempre que não houver estipulação em contrário", não restando dúvidas de que o fiador, para os casos em que a novação era concluída sem o seu consentimento, ficava desonerado de tal ônus, com a novação recuperacional ocorre o contrário.

Na novação recuperacional, embora não exista acordo entre o devedor principal, seu fiador e o credor, quanto a garantia fidejussória, nos casos de novação da obrigação ou dívida afiançada, as normas que prevalecem são as dos arts. $49, \S 1^{\circ}, 59$, caput, e art. $61, \S 2^{\circ}$ da Lei $\mathrm{n}^{\circ} 11.101 / 2005$, a seguir transcritos:

Art. 49. Estão sujeitos à recuperação judicial todos os créditos existentes na data do pedido, ainda que não vencidos.

$\S 1^{\circ}$ Os credores do devedor em recuperação judicial conservam seus direitos e privilégios contra os coobrigados, fiadores e obrigados de regresso.

[...]

Art. 59. O plano de recuperação judicial implica novação dos créditos anteriores ao pedido, e obriga o devedor e todos os credores a ele sujeitos, sem prejuízo das garantias, observado o disposto no $\S 1^{\circ}$ do art. 50 desta lei. [...]

Art. 61. [...]

$\S 2^{\circ}$ Decretada a falência, os credores terão reconstituídos seus direitos e garantias nas condições originalmente contratadas, deduzidos os valores eventualmente pagos e ressalvados os atos validamente praticados no âmbito da recuperação judicial.

Nesse sentido é o entendimento de Manoel Justino Bezerra Filho:

O credor com garantia de terceiro (v.g aval, fiança, etc), mesmo sujeitandose aos efeitos da recuperação, pode executar o garantidor. Um exemplo facilitará o entendimento: suponha-se uma limitada que emitiu uma nota promissória em favor de qualquer credor, tendo o sócio dessa limitada (ou qualquer terceiro) avalizado o título. Mesmo que o crédito esteja sujeito aos efeitos da recuperação, o credor pode executar o avalista. Deverá cuidar para, recebendo qualquer valor em qualquer das ações, comunicar nos autos da outra tal recebimento. Neste caso (aval pleno), não há, por óbvio, qualquer limite ao valor em execução, ante a autonomia das relações cambiais. (BEZERRA FILHO, 2005, p. 146;147) 
Portanto, em sendo concedida a recuperação ${ }^{3}$, fica automaticamente suspensa a previsão do $\S 4^{\circ}$, do art. $6^{\circ}$ da Lei $\mathrm{n}^{\circ} 11.101 / 2005^{4}$, permanecendo suspensas todas as ações e as execuções contra o devedor. Entretanto, as execuções contra os coobrigados não sofrem nenhum tipo de interferência, nos termos do disposto no $\S 1^{\circ}$, do art. 49 , reiterado no art. 59, ambos da Lei $\mathrm{n}^{\circ} 11.101 / 2005$.

Em que pese o fato de a maior parte da doutrina acompanhar o entendimento supra expendido, existem divergências, autores que interpretam a novação recuperacional como sendo uma novação civil. É o caso de Rachel Sztajn, que aduz:

$O$ art. 59, que faz remissão ao art. 50, $\S 1^{\circ}$, reproduz a norma em comento pelo que se deve considerar que interessa saber da possibilidade de exigir ou excutir as garantias relativamente a tais créditos. Mantendo-se alguma coerência entre o sistema jurídico e o objetivo da nova lei, sugere-se interpretar o parágrafo no sentido de que as garantias, como acessório, seguem o principal, o crédito. Em assim sendo, ficam ela subordinadas às mesmas condições que incidam sobre os créditos garantidos, ou seja, não podem ser excutidas de imediato. (SZTAJN, 2006, p. 229)

No mesmo esteio é a posição de Eduardo Secchi Munhoz, ao afirmar:

A parte final do "caput" do dispositivo estabelece que a novação decorrente da aprovação do plano de recuperação ocorre sem prejuízos das garantias, observado o disposto no $\$ 1^{\circ}$ do art. 50. Uma interpretação possível seria a de que a lei pretendeu ressalvar dos efeitos da novação todas as garantias, permanecendo obrigados perante os credores, por exemplo, os fiadores ou

${ }^{3}$ Nos termos do art. 58 da Lei $n^{\circ} 11.101 / 2005$, que diz:

Art. 58. Cumpridas as exigências desta Lei, o juiz concederá a recuperação judicial do devedor cujo plano não tenha sofrido objeção de credor nos termos do art. 55 desta Lei ou tenha sido aprovado pela assembléia-geral de credores na forma do art. 45 desta Lei.

\$ 1 o O juiz poderá conceder a recuperação judicial com base em plano que não obteve aprovação na forma do art. 45 desta Lei, desde que, na mesma assembléia, tenha obtido, de forma cumulativa:

$I$ - o voto favorável de credores que representem mais da metade do valor de todos os créditos presentes à assembléia, independentemente de classes;

II - a aprovação de 2 (duas) das classes de credores nos termos do art. 45 desta Lei ou, caso haja somente 2 (duas) classes com credores votantes, a aprovação de pelo menos 1 (uma) delas;

III - na classe que o houver rejeitado, o voto favorável de mais de 1/3 (um terço) dos credores, computados na forma dos \$\$ 1o e 2 o do art. 45 desta Lei.

$\S 2$ o A recuperação judicial somente poderá ser concedida com base no $\$ 1$ lo deste artigo se o plano não implicar tratamento diferenciado entre os credores da classe que o houver rejeitado.

${ }^{4}$ Da Lei $n^{\circ}$ 11.101/2005 - Art. 6. A decretação da falência ou o deferimento do processamento da recuperação judicial suspende o curso da prescrição e de todas as ações e execuções em face do devedor, inclusive aqueles dos credores particulares do sócio solidário. [...]

$\S 4^{\circ} \mathrm{Na}$ recuperação judicial, a suspensão de que trata o caput deste artigo em hipótese nenhuma excederá o prazo improrrogável de 180 (cento e oitenta) dias contado do deferimento do processamento da recuperação, restabelecendo-se, após o decurso do prazo, o direito dos credores de inicia ou continuar suas ações e execuções, independentemente de pronunciamento judicial. 
quaisquer terceiros que tenham oferecido bens de sua propriedade em garantia da dívida. Essa, porém, não parece constituir a interpretação adequada da norma, por conflitar com a disciplina da novação, tal como regulada no Código Civil. Em regra, segundo a lei civil, a novação extingue os acessórios e garantias da dívida novada, admitindo-se que as partes estipulem em contrário... (MUNHOZ, 2006, p. 293)

O entendimento dos autores Rachel Sztajn e Eduardo Secchi Munhoz é minoritário na doutrina brasileira, o que corrobora a intenção do legislador ao instituir uma novação recuperacional, com a utilização das bases institucionais da novação prevista no Código Civil, mas com as adaptações necessárias, impostas pela recuperação judicial.

\section{O ENTENDIMENTO JURISPRUDENCIAL SOBRE A NOVAÇÃO RECUPERACIONAL}

A jurisprudência do STJ tem o entendimento majoritário de que, com a homologação do plano de recuperação judicial, suspendem-se as ações contra o devedor e sócios solidários (arts. $6^{\circ}$ e 52, inciso II da Lei $\mathrm{n}^{\circ} 11.101 / 2005$ ), mas essa suspensão não alcança os devedores solidários, como avalistas e fiadores, por força do disposto no $\S 1^{\circ}$ do art. 49 da Lei $\mathrm{n}^{\circ}$ $11.101 / 2005$.

A fim de comprovar o acima alegado, tem-se o seguinte precedente, do STJ:

DIREITO EMPRESARIAL E PROCESSUAL CIVIL. RECURSO ESPECIAL. EXECUÇÃO AJUIZADA EM FACE DE SÓCIO-AVALISTA DE PESSOA JURÍDICA EM RECUPERAÇÃO JUDICIAL. SUSPENSÃO DA AÇÃO. IMPOSSIBILIDADE. PENHORA VIA BACEN-JUD. ESGOTAMENTO DOS MEIOS APTOS A GARANTIR A EXECUÇÃO. DESNECESSIDADE.

1. $O$ caput do art. $6^{\circ}$ da Lei $n$. 11.101/05, no que concerne à suspensão das ações por ocasião do deferimento da recuperação, alcança apenas os sócios solidários, presentes naqueles tipos societários em que a responsabilidade pessoal dos consorciados não é limitada às suas respectivas quotas/ações.

2. Não se suspendem, porém, as execuções individuais direcionadas aos avalistas de título cujo devedor principal é sociedade em recuperação judicial, pois diferente é a situação do devedor solidário, na forma do $\$ 1^{\circ}$ do art. 49 da referida lei. De fato, "[a] suspensão das ações e execuções previstas no art. $6^{\circ}$ da Lei $n$. 11.101/05 não se estende aos coobrigados do devedor" (Enunciado n. 43 da I Jornada de Direito Comercial CJF/STJ). [...] (Resp. 1.269.703, Rel. Ministro Luis Felipe Salomão, Quarta Turma, julgado em 13/11/2012, DJe 30/11/2012)

Após a aprovação do plano de recuperação judicial e sua homologação pelo Poder Judiciário, opera-se a novação recuperacional dos créditos, com a constituição de novo título executivo judicial, nos termos do disposto no art. 59, caput e $\S 1^{\circ}$ da Lei ${ }^{\circ} 11.101 / 2005$. 
Entretanto, mesmo que a novação da dívida constitua um novo título executivo, as garantias são preservadas, e podem ser executadas, caso o plano de recuperação não atinja seu fim no prazo de dois anos, contados da sua homologação, ou que seja decretada a falência da empresa em recuperação.

Sobre o assunto, assim se manifestou o Ministro Relator Luis Felipe Salomão, da Quarta Turma do STJ, no Recurso Especial n 1.326.888-RS, julgado em 08/04/2014, em seu voto:

Com efeito, percebe-se que a novação prevista na lei civil é bem diversa daquela disciplinada na Lei n. 11.101/2005. Se a novação civil faz, como regra, extinguir as garantias da divida, inclusive as reais prestadas por terceiros estranhos ao pacto (art. 364 do Código Civil), a novação decorrente do plano de recuperação traz, como regra, ao reverso, a manutenção das garantias (art. 59, caput, da Lei n. 11.101/2005), sobretudo as reais, as quais só serão suprimidas ou substituídas "mediante aprovação expressa do credor titular da respectiva garantia”, por ocasião da alienação do bem gravado (art. 50, $\$ 1^{\circ}$ ).

Por outro lado, a novação específica da recuperação desfaz-se na hipótese de falência, quando então os "credores terão reconstituídos seus direitos e garantias nas condições originalmente contratadas" (art. 61, § $2^{\circ}$ ).

Daí se conclui que o plano de recuperação judicial opera uma novação sui generis e sempre sujeita a uma condição resolutiva, que é o eventual descumprimento do que ficou acertado no plano, circunstância que a diferencia, sobremaneira, daqueloutra, comum, prevista na lei civil.

[...]

Portanto, muito embora o plano de recuperação judicial opere novação das dívidas a ele submetidas, as garantias reais ou fidejussórias, de regra, são preservadas, circunstância que possibilita ao credor exercer seus direitos contra terceiros garantidores e impõe a manutenção das ações e execuções aforadas em face de fiadores, avalistas ou coobrigados em geral.

Deveras, não haveria lógiva no sistema se a conservação dos direitos e privilégios dos credores contra coobrigados, fiadores e obrigados de regresso (art. 49, $\S 1^{\circ}$, da Lei $n .11 .101 / 2005$ ) dissesse respeito apenas ao interregno temporal que medeia o deferimento da recuperação e a aprovação do plano, cessando tais direitos após a concessão definitiva com a homologação judicial.

Já o Ministro Aldir Passarinho, também da Quarta Turma do STJ, em decisão monocrática proferida no Agravo de Instrumento ${ }^{\circ} 1.077 .960 / \mathrm{SP}^{5}$, considerou que, a suspensão

\footnotetext{
${ }^{5}$ Trecho da decisão proferida no Ag. 1.077 .960 - [...] De fato, é entendimento desta Corte que não se mostra consentâneo com a recuperação judicial o prosseguimento de execuções individuais, devendo estas ser suspensas e pagos os créditos, doravante novados, de acordo com o plano de recuperação homologado em juízo. A saber:

"CONFLITO POSITIVO DE COMPETÊNCIA. VIAÇÃO AÉREA SÃO PAULO S.A - VASP. EMPRESA EM RECUPERAÇÃO JUDICIAL. SUSPENSÃO DAS EXECUÇÕES INDIVIDUAIS. NECESSIDADE.

1. O conflito de competência não pode ser estendido de modo a alcançar juízos perante os quais este não foi instaurado.
} 
de execuções em face do devedor principal, durante o período de recuperação judicial da empresa, deve ser estendida, também, aos avalistas, devendo a execução acontecer apenas se não houver a satisfação do credito com o plano de recuperação judicial, ou em sendo decretada a falência da empresa.

Dessa maneira, assim como na doutrina, a jurisprudência ainda não é unânime sobre os efeitos da novação recuperacional, principalmente com relação as garantias, uma vez que, ao contrário da lei civil, que é expressa ao dizer que a novação extingue as garantias, salvo estipulação em contrário; a Lei de Falência e Recuperação é expressa ao dizer que a novação não extingue as garantias, salvo estipulação em contrário.

\section{CONCLUSÃO}

Neste trabalho, foi colocado para discussão um tema que ainda apresenta divergências doutrinárias e jurisprudenciais, com grande relevância no processo concursal, qual seja, a existência ou não de igualdade no instituto da novação disciplinado na Lei Civil e o previsto na Lei de Recuperação e Falência.

Como analisado, a novação recuperacional possui os mesmos requisitos da novação prevista na Lei Civil, e, portanto, aquela não deve ser considerada uma forma autônoma de

2. Aprovado o plano de recuperação judicial, os créditos serão satisfeitos de acordo com as condições ali estipuladas. Nesse contexto, mostra-se incabível o prosseguimento das execuções individuais. Precedente.

3. Conflito parcialmente conhecido para declarar a competência do Juízo da $1^{a}$ Vara de Falências e Recuperações Judiciais do Foro Central de São Paulo - SP." (2 $2^{a}$ Seção, CC n. 88.661/SP, Rel. Min. Fernando Gonçalves, unânime, DJe de 03.06.2008)

Destarte, se suspensa a execução em relação ao devedor principal, evidentemente razão não há para que se prossiga na persecução do crédito pela via executiva contra o avalista. Nesse sentido:

"CIVIL. EXECUÇÃO. NOVAÇÃO. SUSPENSÃO.

1. NÃO HÁ NOVAÇÃO QUANDO OS FIGURANTES DE ACORDO EXPRESSAMENTE AFASTAM A INTENÇÃO DE NOVAR, ATÉ PORQUE A DEVEDORA RECONHECE A EXISTÊNCIA INTEGRAL DA DÍVIDA E APENAS SE OBRIGA A PAGÁ-LA PARCIALMENTE EM PRESTAÇÕES.

2. A SUSPENSÃO DA EXECUÇÃO, EM RELAÇÃO AO DEVEDOR PRINCIPAL ACARRETA A SUSPENSÃO QUANTO AOS AVALISTAS, POSTO QUE DECISÃO COM TRÂNSITO EM JULGADO DETERMINA QUE OS BENS DOS AVALISTAS, QUE SE ACHEM PENHORADOS, SOMENTE SEJAM LEVADOS A ARREMATAÇÃO SE INSUFICIENTE O PRODUTO DA ARREMATAÇÃO DOS BENS DA DEVEDORA PRINCIPAL" (4ª Turma, REsp n. 35.311/SP, Rel.

Min. Dias Trindade, unânime, DJU de 20.09.1993)

Ante o exposto, atento ao artigo 544, $\S 3^{\circ}$, do Código de Processo Civil, conheço do presente agravo e dou provimento ao próprio recurso especial para suspender a execução, cujo deslinde do processo de recuperação judicial da avalizada determinará seu prosseguimento ou extinção, conforme seja declarada a falência ou cumprida a obrigação. [...] 
novação, mas sim como uma espécie, uma vez que a novação recuperacional nada mais é do que uma Novação Condicional ou Resolutiva.

A novação recuperacional está sempre sujeita a uma condição resolutiva, qual seja o eventual descumprimento do Plano de Recuperação, com a convolação da falência, de maneira que, se há esse descumprimento, as garantias reais das dívidas novadas podem ser executadas pelos credores.

Portanto, a Lei de Falência e Recuperação (Lei n ${ }^{11.101 / 2005), ~ a o ~ p r e v e r ~ u m a ~ n o v a c ̧ a ̃ o ~}$ condicional ou resolutiva, o faz em razão do seu objetivo principal, que é conceder as empresas em crise uma possibilidade de recuperação, em um momento de crise, mas também visa proteger os interesses dos credores.

Dessa maneira, a novação recuperacional não deve ser considerada uma forma autônoma de novação, e nem um instituto completamente diverso da novação prevista na Lei Civil, sendo, o correto, considerá-la como uma espécie de novação condicional ou resolutiva, a fim de atender aos requisitos e necessidades impostos pela Lei de Falência e Recuperação.

\section{REFERÊNCIAS}

BEZERRA FILHO, Manoel Justino. Lei de recuperação de empresas e falências: Comentada: Lei 11.101 de 9 de fevereiro de 2005: comentado artigo por artigo. 5. ed. São Paulo: Revista dos Tribunais, 2008.

BRASIL. Constituição da República Federativa do Brasil de 1988. Disponível em <http://www.planalto.gov.br/ccivil_03/Constituicao/Constituicao.htm> Acesso em 2401/2016.

BRASIL. Decreto-Lei $n^{\circ}$ 7.661, de 21 de junho de 1945. Revogado pela Lei ${ }^{\circ} 11.101$ de 2005. Disponível em < http://www.planalto.gov.br/ccivil_03/decreto-lei/Del7661.htm>. Acesso em 28/03/2016.

BRASIL. Lei $n^{o}$ 10.406, de 10 de janeiro de 2002. Institui o Código Civil. Disponível em: <http://www.planalto.gov.br/ccivil_03/leis/2002/L10406.htm>. Acesso em 18/01/2016.

BRASIL. Lei $n^{\circ} 11.101$, de 9 de fevereiro de 2005. Regula a recuperação judicial, a extrajudicial e a falência do empresário e da sociedade empresária. < http://www.planalto.gov.br/ccivil_03/_ato2004-2006/2005/lei/111101.htm>. Acesso em 28/03/2016.

BRASIL. Superior Tribunal de Justiça. Recurso especial $n^{\circ} 1.326 .888 / R S$, da $4^{\text {a }}$ Turma, Brasília, Distrito Federal, Acórdão julgado em 8 de abril de 2014. Disponível em <https://ww2.stj.jus.br/processo/revista/documento/mediado/?componente=ITA\&sequencial= $1312526 \&$ num_registro $=201201162712 \&$ data $=20140505 \&$ formato $=P D F>$. Acesso dia 28/03/2016. 
BRASIL. Superior Tribunal de Justiça. Agravo de Instrumento $n^{\circ} 1.077 .960 / S P$, da $4^{\text {a }}$ Turma, Brasília, Distrito Federal, Decisão monocrática publicada em 4 de agosto de 2009. Disponível em<https://ww2.stj.jus.br/processo/revista/documento/mediado/?componente=MON\&sequen cial $=5667462 \&$ num_registro $=200801427445 \&$ data $=20090804 \&$ formato $=P D F>$. Acesso em 28/03/2016.

DINIZ, Maria Helena. Curso de direito Civil brasileiro: teoria geral das obrigações. $22^{\mathrm{a}}$ ed. São Paulo: Saraiva, 2007.

FAZZIO JÚNIOR, Waldo. Lei de falências e concordatas comentada. ed. São Paulo: Atlas, 2003. . Manual de direito comercial. 3. ed. São Paulo: Atlas, 2003. Fundamentos de direito comercial. 4. ed. São Paulo: Altas, 2003. Lei de Falência e Recuperação de Empresas. $5^{\text {a }}$ ed. Atlas, 2010.

FRANCO, Vera Helena de Mello. SZTAJN, Rachel. Falência e recuperação da empresa em crise. Rio de Janeiro: Elsevier, 2008.

GOMES, Orlando. Direito civil: obrigações. 17ª ed. Rio de Janeiro: Forense, 2008.

LOBO, Jorge. Arts. 34 à 69. In: Toledo, Paulo F. C. Salles; ABRÃO, Carlos Henrique (Coord.). Comentários à lei de recuperação de empresas e falência. São Paulo: Saraiva, 2010.

LOBO, Jorge Joaquim. Direito concursal. Rio de Janeiro: Forense, 1996.

O moderno direito concursal. RDM 99/89. São Paulo: Revista dos Tribunais, 1995.

GAGLIANO, Pablo Stolze. PAMPLONA FILHO, Rodolfo. Novo Curso de direito civil. V. II: obrigações. 12a ed. São Paulo: Saraiva, 2011.

MIRANDA, Pontes de. Tratado de Direito Privado - Parte Especial. Tomo XXV. $3^{\text {a }}$. ed. São Paulo: Revista dos Tribunais, 1984.

MUNHOZ, Eduardo S. Da recuperação judicial. SOUZA JUNIOR, Francisco Satiro de; PITOMBO, Antônio Sérgio A. de Moraes. Comentários à lei de recuperação de empresas e falência-Lei 11.101/2005. São Paulo: Revista dos Tribunais, 2006.

PEREIRA, Caio Mário da Silva. Instituições de direito civil - Teoria geral das obrigações. V. II. $20^{\mathrm{a}}$ edição. Rio de Janeiro: Forense, 2005.

SZTAJN, Rachel. Da recuperação judicial. In: SOUZA JÚNIOR, Francisco Sátiro; PITOMBO, Antônio Sérgio A. de Moraes (Coord.). Comentários à lei de recuperação de empresas e falência. São Paulo: Revista dos Tribunais, 2006.

TARTUCE, Flávio. Direito civil: direito das obrigações e responsabilidade civil. V. 2. $10^{\mathrm{a}}$ ed. São Paulo: Método, 2015. 